\title{
Klasifikacija, epidemiologija, faktori rizika i primarna prevencija ishemijske bolesti srca
}

\author{
Nataša Mickovski ${ }^{1}$, Branko Jakovljević ${ }^{2}$ Mirjana Lapčević ${ }^{3}$ \\ Institut za javno zdravlje „Dr Milan Jovanović Batut”"; Institut za higijenu i medicinsku ekologiju, \\ Medicinski fakultet, Univerzitet u Beogradu²; Dom zdravlja Voždovac
}

\section{Definicije i klasifikacije entiteta}

K ardiovaskularne bolesti (KVB) predstavljaju veliku i heterogenu grupu oboljenja, koja prema desetoj reviziji međunarodne klasifikacije bolesi (MKB10) obuhvata sledeće poremećaje zdravlja (Tabela 1.1): akutnu reumatsku groznicu, hronične reumatske bolesti srca, bolesti prouzrokavane povišenim krvnim pritiskom, ishemijsku bolest srca (koronarnu bolest srca), bolesti srca plućnog porekla i bolesti krvnih sudova pluća, bolesti krvnih sudova mozga, bolesti arterija, malih arterija i kapilara, vena, limfnih sudova i limfnih čvorova i druge neoznačene bolesti srca i krvotoka ${ }^{1}$. Ishemijska bolest srca (IBS) je najčešća bolest iz ove velike grupe.

Tabela 1.1. Kardiovaskularne bolesti i njihove šifre prema MKB 10

\begin{tabular}{|l|l|}
\hline Bolest & Šifra \\
\hline Bolesti sistema krvotoka & $100-199$ \\
\hline Akutna reumatska groznica & $100-102$ \\
\hline Hronične reumatske bolesti srca & $105-109$ \\
\hline Bolesti uzrokovane povišenim krvnim pritiskom & $110-115$ \\
\hline Ishemijske bolesti srca & $120-125$ \\
\hline Bolesti srca plućnog porekla i bolesti krvnih sudova pluća & $126-128$ \\
\hline Druge bolesti srca & $130-152$ \\
\hline Bolesti krvnih sudova mozga & $160-169$ \\
\hline Bolesti arterija, malih arterija i kapilara & $170-179$ \\
\hline Bolesti vena, limfnih sudova i limfnih čvorova & $180-189$ \\
\hline Druge i neoznačene bolesti krvotoka & $195-199$ \\
\hline
\end{tabular}

\section{Deskriptivno-epidemiološke karakteristike KVB i IBS}

Bolesti srca i krvnih sudova su već decenijama unazad vodeći uzrok obolevanja, radne nesposobnosti, izostajanja sa posla i prevremene smrtnosti (pre 65. godine) u razvijenim zemljama i u zemljama u razvoju².

Na početku 20. veka od KVB umirao je tek svaki 10 stanovnik, da bi se na početku 21 . veka, usled nove faze tzv. epidemiološke tranzicije, taj broj povećao na $30 \%$. Svake godine od kardiovaskularnih bolesti umre preko 17 miliona stanovnika, dok samo od AIM oboli preko 6 miliona stanovnika, od čega se smrtni ishod javlja kod približno $25 \%$ slučajeva ${ }^{3}$. lako se različite zemlje nalaze u različitim fazama tranzicije, predviđa se da će do 2020. godine bolesti srca i krvnih sudova postati vodeći uzrok umiranja u svim zemljama, naročito u nerazvijenim. Već sada je procenjeno da preko $80 \%$ smrtnosti od svih KVB i $60 \%$ opterećenja od IBS potiče iz zemalja u razvoju i nerazvijenih zemalja ${ }^{4}$.

Sam proces „epidemiloške tranzicije“ ne podrazumeva samo promene u strukturi oboljevanja i umiranja, već se ogleda i u promenama u okviru iste grupe oboljenja (npr. pad učestalosti oboljevanja od reumatske groznice kod mladih, a češća pojava IBS kod radno-aktivnog stanovništva). Zbog toga danas u svetu u strukturi umiranja od kardiovaskularnih bolesti dominira mortalitet od IBS, nakon čega sledi umiranje od cerebrovaskularnih i drugih bolesti srca i krvnih sudova ${ }^{5}$. Zbog toga danas u svetu, u strukturi umiranja od kardiovaskularnih bolesti dominira mortalitet od IBS, nakon čega sledi umiranje od cerebrovaskularnih i drugih bolesti srca i krvnih sudova. 
U Srbiji je situacija naizgled drugačija, verovatno i zbog neadekvatnog šifriranja osnovnog uzroka smrti. Vrlo veliki broj umrlih od IBS se „krije” u podgrupi umrlih od ostalih KBV (u Srbiji je u poređenju sa svetom duplo veći procenat umrlih svrstan u grupu ostale KVB, a skoro duplo manji u grupu IBS) (Grafikon 1.1).

Međutim, detaljnijom analizom pojedinačnih uzroka smrti, u strukturi svih uzroka smrtnog ishoda, smrtnost od pojedinih kliničkih oblika IBS je među prvih deset. Usled pomeranja uzrasne granice oboljevanja i umiranja od IBS, kod osoba uzrasta od 20 do 64 godine, smrtnost od akutnog infarkta miokarda je već na drugom mestu, iza mortaliteta od raka pluća.

Na Grafikonu 1.2 prikazan je trend umiranja od KVB u periodu od 2000. do 2009. godine. U desetogodišnjem periodu posmatranja, kod osoba oba pola, registrovan je trend smanjenja umiranja od svih KVB.

Kao rezultat dugoročnog poboljšanja socijalno-ekonomskih uslova, kvaliteta zdravstvene zaštite i promocije zdravih stilova života u periodu od sedamdesetih do devedesetih godina prošlog veka, u visoko razvijenim zemljama registruje se tendencija pada umiranja od bolesti srca i krvnih sudova 5 . Ta razlika je očigledna ukoliko se posmatraju samo zemlje Evrope: s jedne strane nalaze se razvijene zemlje zapadne Evrope, gde smrtrnost pada, a s druge strane nalaze se zemlje istočne Evrope.

Iz tih razloga stope umiranja od IBS najviše su u zemljama istočne Evrope, posebno u zemljama bivšim članicama Varšavskog pakta (Tabela 1.2). U poređenju sa drugim zemljama evropskog regiona, koje su dostavile mortalitetne podatke za 2009. godinu, Srbija se sa stopom od 113,8/100.000 nalazila u grupi zemalja sa srednjim rizikom umiraja od IBS. Rizik umiranja je verovatno daleko viši, ali je odraz već napred pomenutog neadekvatnog šifriranja osnovnog uzroka smrti.

Stope mortaliteta više nisu tako pouzdan pokazatelj zdravstvenog stanja stanovništva. Zbog toga se sve više u proceni zdravstvenog stanja populacije koriste tzv. kompozitni pokazatelji, među kojima je i DALY (Disability adjusted life years - godine života korigovane u odno-

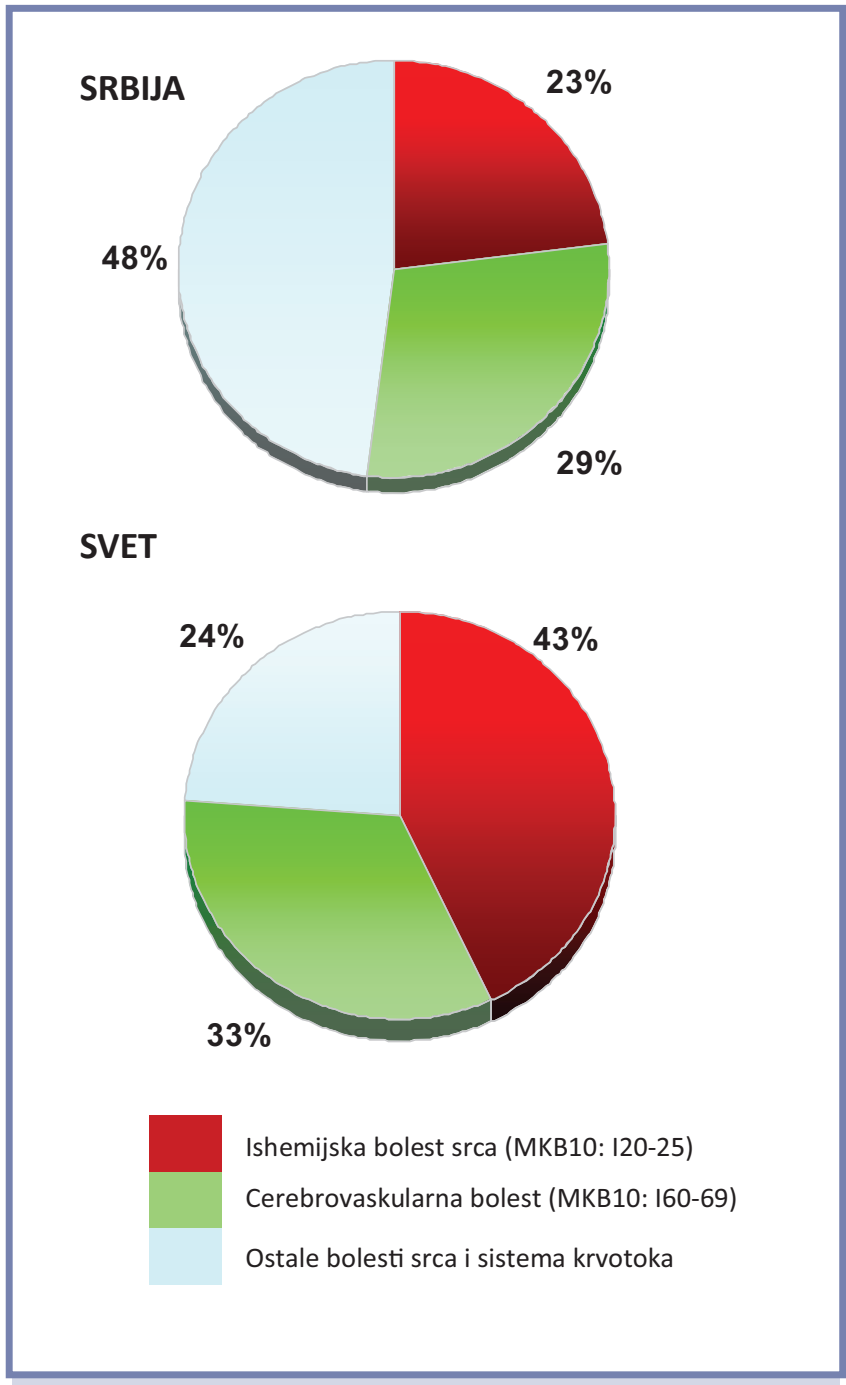

Grafikon 1.1. Struktura umiranja od kardiovaskularnih bolesti u Srbiji (levo) tokom 2009 godine i svetu (desno) tokom 2008. godine

Izvor: Institut za javno zdravlje Srbije, 2010; WHO, Noncommunicable Diseases, 2008

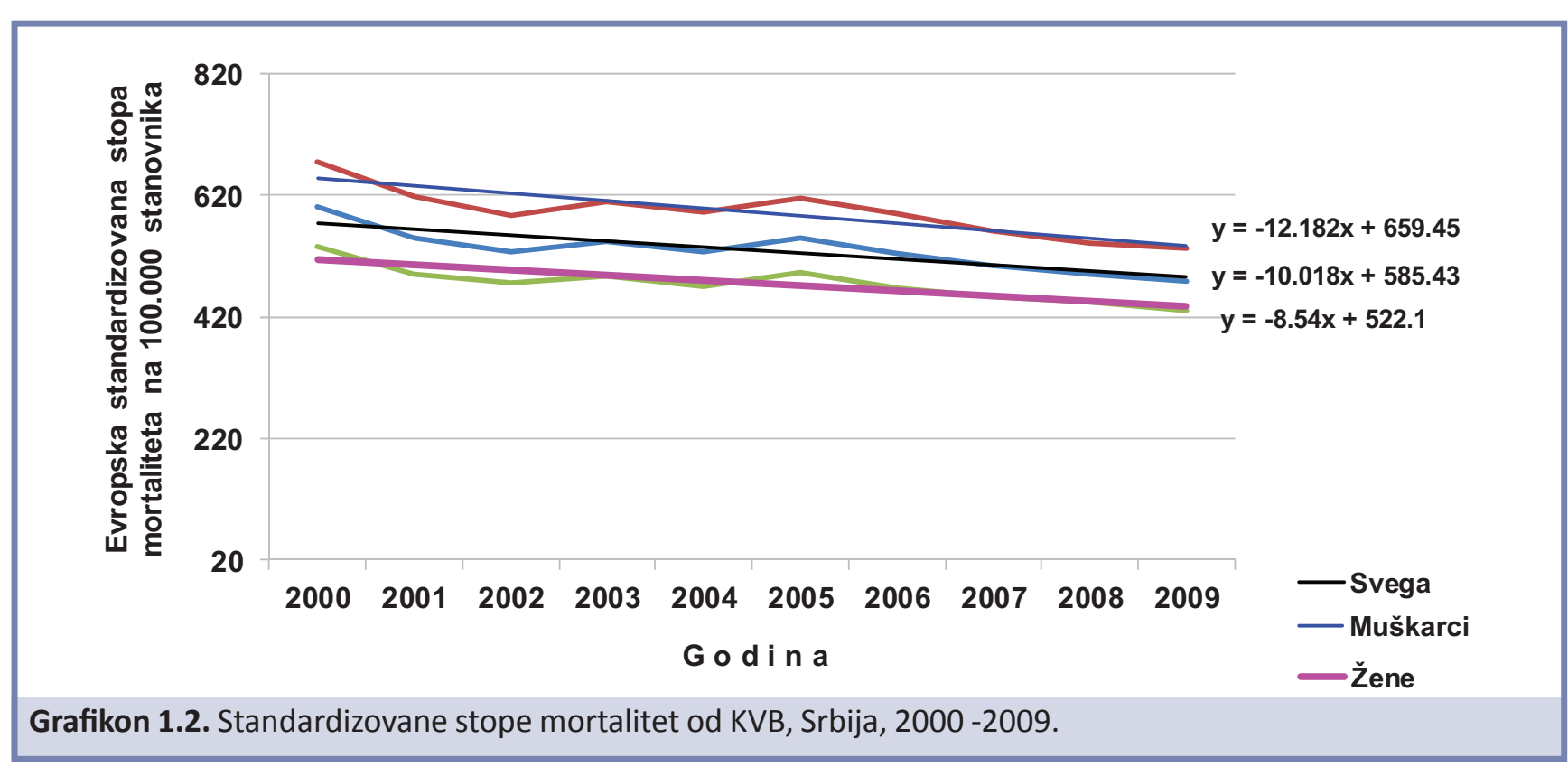

Izvor: Institut za javno zdravlje Srbije, 2010 
Tabela 1.2. Standardizovane stope mortaliteta od IBS u Srbiji i pojedinim zemljama evropskog regiona, 2009.

\begin{tabular}{|c|c|}
\hline Zemlja & Standardizovane stope mortaliteta na 100000 \\
\hline Kirgistan & 420,1 \\
\hline Litvanija & 305,1 \\
\hline Mađarska & 214,8 \\
\hline Evropski region & 193,3 \\
\hline Rumunija & 188,8 \\
\hline Češka & 170,1 \\
\hline Hrvatska & 157,8 \\
\hline Finska & 122,5 \\
\hline Srbija & 113,8 \\
\hline Irska & 103,1 \\
\hline Austrija & 97,8 \\
\hline Evropska unija & 87,2 \\
\hline Island & 83,3 \\
\hline Velika Britanija & 80,8 \\
\hline Grčka & 67,4 \\
\hline Norveška & 65,9 \\
\hline Holandija & 43,9 \\
\hline Portugal & 42,2 \\
\hline
\end{tabular}

Izvor: HFA-DB, WHO 2009

Tabela 1.3. Teret bolesti za pojedinačne poremećaje zdravlja (DALY's u \%), Srbija i Evropa, 2000.

\begin{tabular}{|c|l|r|l|c|}
\hline Rang & Srbija & \multicolumn{1}{c|}{$\%$} & Evropa & $\%$ \\
\hline 1 & Ishemijske bolesti & 23,8 & Ishemijske bolesti & 24,8 \\
\hline 2 & Cerebrovaskularne bolesti & 22,3 & Cerebrovaskularne bolesti & 19,1 \\
\hline 3 & Rak bronha i pluća & 9.0 & Depresija & 9,2 \\
\hline 4 & Dijabetes & 6,1 & Rak bronha i pluća & 3,8 \\
\hline 5 & Depresija & 5,1 & Infekcije donjeg respiratornog sis. & 3,1 \\
\hline 6 & Saobraćajni traumatizam & 4,2 & Hr. opstruktivna bolest pluća & 2,9 \\
\hline 7 & Rak dojke & 4.0 & Rak kolona i rektuma & 2,4 \\
\hline 8 & Samo povređivanje & 3,9 & Samopovređivanje & 1,8 \\
\hline 9 & Rak kolona i rektuma & 3,2 & Hipertenzivna bolest srca & 1,8 \\
\hline 10 & Rak želuca & 2,6 & Rak želuca & 1,8 \\
\hline 11 & Nefritis i nefroza & 2,3 & Ciroza jetre & $U$ \\
\hline 12 & Porođajna asfiksija i trauma & 2.0 & Rak dojke & 1,6 \\
\hline 13 & Astma & 1,9 & Kongenitalne anomalije & 1,5 \\
\hline 14 & Hipertenzivna bolest srca & 1,6 & Dijabetes & 1,5 \\
\hline 15 & Rak jetre & 1,1 & Saobraćajni traumatizam & 1,3 \\
\hline 16 & Rak pankreasa & 1.0 & Trovanja & 1,1 \\
\hline 17 & Mala telesna težina na rođenju & 0,8 & Rak prostate & 1.0 \\
\hline 18 & Tuberkuloza & 0,5 & Tuberkuloza & 0,8 \\
\hline $1 \$$ & Gubitak vida i sluha & 0,4 & Nefritis i nefroza & 0,8 \\
\hline 20 & HIV/AIDS & 0,3 & HIV/AIDS & \\
\hline & Ukupno prvih 20 uzoraka & Ukupno prvih 20 uzoraka & \\
\hline & & & \\
\hline
\end{tabular}


su na nesposobnost). DALY odražava opterećenje određenom bolešću, jer pored mortaliteta, analizira i morbiditet od određenog oboljenja.

Ukupno opterećenje oboljevanjima u Srbiji bilo je najvećim delom uzrokovano IBS, kao i u ostalim zemljama Evrope (Tabela 1.3). Opterećenje IBS je veće kod muškaraca nego kod žena i raste sa godinama života (Tabela 1.4). Najveći porast očekivanog trajanja života na rođenju u Srbiji nastao bi eliminacijom prevremenog mortaliteta od IBS kod muškaraca (2,4 godine), odnosno eliminacijom prevremenog umiranja od CVB kod žena (2,1 godina $)^{6}$.

Tabela 1.4. DALY za 18 izabranih poremećaja zdravlja u odnosu na pol, Srbija, 2000.

\begin{tabular}{|c|l|c|l|l|}
\hline Rang & muškarci poremećaj zdravlja & \multicolumn{1}{|c|}{ \%* $^{*}$} & žene poremećaj zdravlja & \%* \\
\hline 1. & ishemiska bolest srca & 27,64 & cerebrovaskularne bolesti & 25,59 \\
\hline 2. & cerebrovaskularne bolesti & 18,04 & ishemiska bolest srca & 19,98 \\
\hline 3. & rak pluća & 13,40 & depresija & 12,32 \\
\hline 4. & saobraćajni traumatizam & 6,92 & rak dojke & 8,57 \\
\hline 5. & samoubistvo & 6,34 & dijabetes & 7,35 \\
\hline 6. & depresija & 5,49 & rak pluća & 4,57 \\
\hline 7. & dijabetes & 4,93 & kolorektalni rak & 3,82 \\
\hline 8. & kolorektalni rak & 4,47 & rak grlića materice & 3,00 \\
\hline 9. & rak želuca & 3,11 & nefritis i nefroza & 2,48 \\
\hline 10. & porođajna asfiksija i trauma & 2,33 & saobraćajni traumatizam & 2,34 \\
\hline 11. & nefritis i nefroza & 2,14 & samoubistvo & 2,15 \\
\hline 12. & astma & 2,11 & rak želuca & 2,07 \\
\hline 13. & mala felesna težina na rođenju & 0,73 & astma & 1,06 \\
\hline 14. & tuberkoloza & 0,70 & porođajna asfiksija i trauma & 1,98 \\
\hline 15. & HIV/AIDS & 0,35 & mala felesna težina na rođenju & 1,82 \\
\hline 16. & gubitak vida i sluha & 0,30 & gubitak vida i sluha & 0,43 \\
\hline 17. & rak dojke & 0,09 & tuberkoloza & 0,29 \\
\hline 18. & & - & HIV/AIDS & 0,19 \\
\hline
\end{tabular}

Izvor: Opterećenje bolestima i povredama u Srbji, 2003.

Kao najteži oblik IBS, akutni koronarni sindrom (AKS) je jedan od najčešćih uzroka hitnog prijema i iznenadne smrti u razvijenim delovima sveta, a poslednjih decenija i u zemljama u razvoju ${ }^{7,8}$.

Prema poslednjim raspoloživim podacima registra za akutni koronarni sindrom u Srbiji, tokom 2009. godine ova akutna forma ishemijske bolesti srca je dnevno registrovana kod 63 osobe. Iste godine

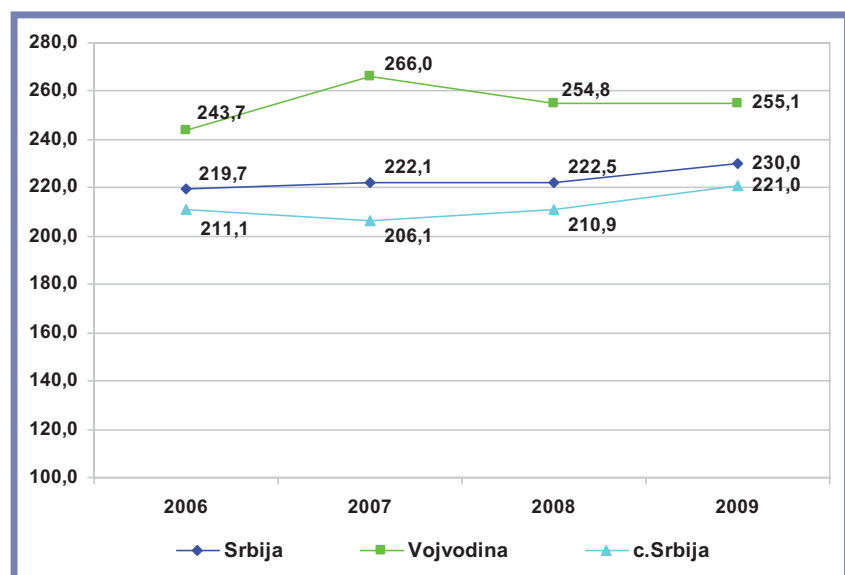

Grafikon 1.3. Standardizovane stope incidencije* od akutnog koronarnog sindroma u Srbiji, 2006-2009. dnevno je od akutnog infarkta miokarda umiralo 18 osoba ${ }^{9}$.

Stope incidencije od akutnog koronarnog sindroma su generalno više na severu Srbije, u Vojvodini, nego u centralnoj Srbiji, kao što je prikazano na Grafikonu 1.3.

Kao što je prikazano na Grafikonu 1.4, najviše uzrasno-specifične stope incidencije od AKS tokom 2009. godine zabeležene su kod najstarijeg stanovništva.

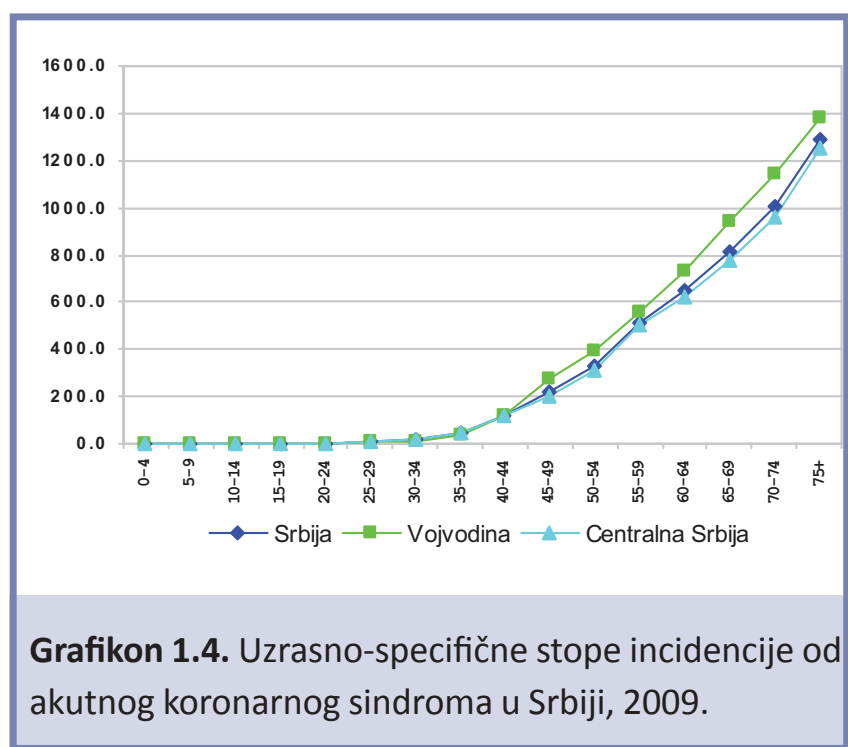




\section{Faktori rizika za ishemijsku bolest srca i primarna prevencija}

Još uvek nije u potpunosti razjašnjena etiopatogeneza IBS. Zato se govori o faktorima rizika koji predisponiraju određene osobe/populaciju da obole od IBS sa većom učestalošću nego populacija koja nije izložena istim faktorima rizika. Glavni nezavisni faktori rizika za pojavu IBS su sledeći: pušenje duvana, povišen krvni pritisak, povećani serumski (ukupni i LDL) holesterol, nizak HDL holesterol, dijabetes melitus, muškarci starosti $>55$ god i žene posle menopauze i starosti $>65$ god, starije životno doba.

Predsiponirajući faktori rizika za nastanak IBS su sledeći: gojaznost, abdominalna gojaznost, mala fizička aktivnost, sedentarni način života, pozitivna porodična anamneza za ishemijsku bolest srca u ranijem životnom dobu ( $<55$ kod muškaraca ; $<65$ godina kod žena), etničke karakteristike, psihosocijalni faktori.

Uslovni faktori rizika za nastanak IBS su sledeći: povišeni trigliceridi, povišene male LDL čestice, povišen homocistein, povišen lipoprotein Lp (a), povišen fibrinogen, povišeni inflamatorni markeri ( $C$ reaktivni protein).

Postoji veći broj skoring sistema za određivanje morbiditeta i mortaliteta od KVB, na osnovu prisustva faktora rizika, a prema rezultatima velikih epidemioloških studija. Evropsko udruženje kardiologa preporučuje upotrebu takozvanih SCORE tablica (Grafikon 1.5) za određivanje desetogodišnjeg mortaliteta od KVB (i IBS i CVB).[7] Ove tablice su napravljene na osnovu rezultata 12 evropskih kohortnih studija sa ukupno 205.178 ispitanika (88.080 žena i 117.098 muškaraca), sa ukupnim praćenjem od 2,7 miliona bolesnik-godina. $U$ tom periodu registrovana su 7.934 smrtna ishoda od KVB od kojih čak 5.652 od IBS.

S obzirom na to da SCORE tablice potcenjuju rizik za mlade osobe, napravljene su i tabele koje definišu relativni kardiovaskularni rizik neke osobe u poređenju sa

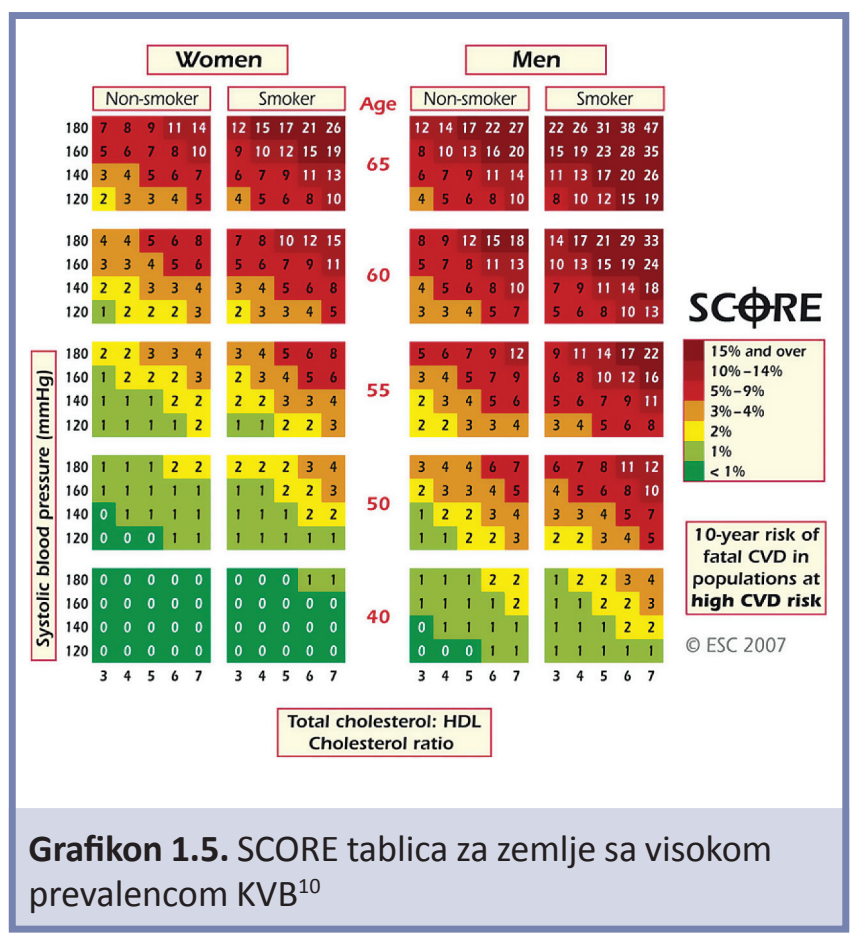

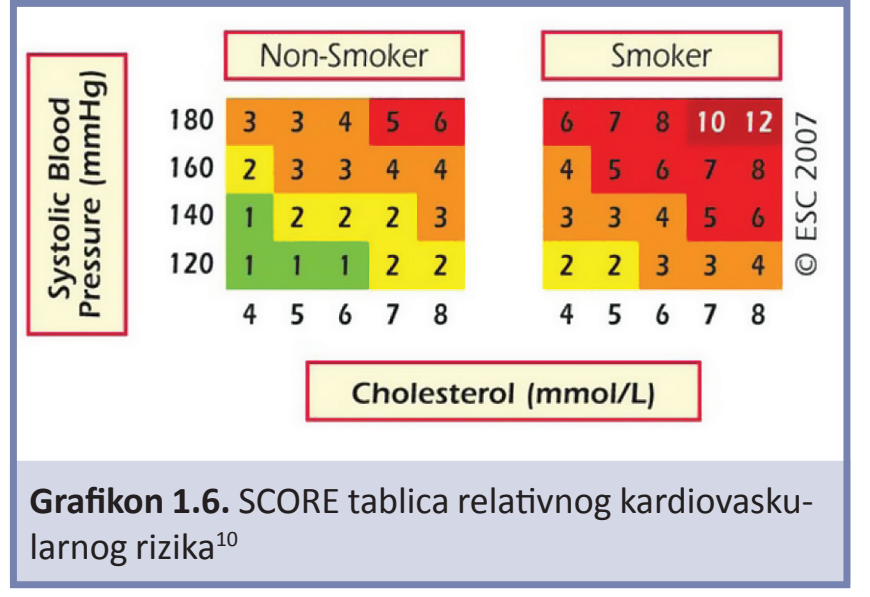

osobama koje nemaju povišen krvni pritisak i holesterol, koje nisu pušači, a istog su pola i uzrasta (Grafikon 1.6).

Evropsko udruženje kardiologa je kao svoj cilj zacrtalo da nijedno novorođeno dete u trećem milenijumu ne umre i ne oboli od KVB pre svoje 65. godine života. Kao primarnu prevenciju preporučilo je „šifru“ koja glasi 0-3-5-140-5-3-0, a koja upućuje na zdrav način života i kontrolu faktora rizika: 0 - bez pušenja (ni aktivno ni pasivno), 3 - preporučuje se najmanje $3 \mathrm{~km}$ šetnje dnevno, 5 - preporučljivo je imati 5 obroka dnevno sa voćem i povrćem (najmanje 400-600 g), 140 - sistolni krvni pritisak manji od $140 \mathrm{mmHg}, 5$ - ukupni holesterol manji od $5 \mathrm{mmol} / \mathrm{l}, 3$ - LDL holesterol manji od $3 \mathrm{mmol} / \mathrm{l}$, 0 - bez gojaznosti i šećerne bolesti.

\section{Literatura}

1. Savezni zavod za zaštitu zdravlja. Međunarodna klasifikacija bolesti, X revizija. Beograd: Savremena administracija, 1996.

2. Mackay J, Mensah G. Atlas of Heart Disease and Stroke. Geneva: WHO; 2004.

3. Burke GL, Bell RA. Trends in Cardiovascular Disease: Incidence and Risk Factors. U knjizi: Wong ND ed. Preventive Cardiology. New York: McGraw-Hill, 2000:21-46.

4. WHO. World Health Report 2004: Changing history, Geneva: WHO, 2004.

5. Gazianao JM. Global burden of cardiovascular disease. U knjizi: Zorab R. ed: Heart Disease. A textbook of cardiovascular medicine. 6th edition. Philadelphia: W.B. Saunders Company, 2001:1-18.

6. Atanasković-Marković $Z$, Bjegović $V$, Janković $S$, et al. The burden of disease and injury in Serbia. Belgrade: Ministry of Health of the Republic of Serbia, 2003.

7. Bertrand ME, Simoons ML, Fox KA, et al. Management of acute coronary syndromes in patients presenting without persistent ST'segment elenation. Eur Heart J 2002;23:1809-1840.

8. Hadsai D, Behar S, Wallentin L, et al. A prospective survey of the characteristics, treatment and outcomes of patients with acute coronary syndromes in Europe and the Mediterranean basin. The Euro Heart Survey of acute coronary syndromes (Euro Heart Survey ACS). Eur Heart J 2002;23:1190-1201.

9. Incidencija i mortalitet od akutnog koronarnog sindroma $u$ 2006, 2007, 2008, 2009, Srbija. Institut za javno zdravlje republike Srbije „Dr Milan Jovanović Batut”, http://www.batut.org.rs

10. Graham I, et al. European guidelines on cardiovascular disease prevention in clinical practice: full text. Fourth Joint Task Force of the European Society of Cardiology and other societies on cardiovascular disease prevention in clinical practice (constituted by representatives of nine societies and by invited experts). Eur J Cardiovasc Prev Rehabil 2007; 14 (Suppl 2): S1-113. 